\title{
Tutuklu-Hükümlü Olan ve Olmayan Gençlerin Ahlaki Gelişim Düzeyleri ve Benlik Saygılarının Karşılaştırılması
}

\author{
Comparison of Moral Development Levels and Self-Esteem Levels of \\ Imprisoned-Convicted Youth and Non imprisoned-Non convicted Youth
} Kızbes Meral KILIÇ* - Fatma Abide GÜNGÖR AYTAR**

Akdeniz Üniversitesi, Çocuk Gelişimi Bölümü, kmeralkilic@akdeniz.edu.tr* Gazi Üniversitesi, Temel Eğitim Bölümü, abidegungor@yahoo.com **

ORCID Numaraları | ORCID Numbers: 0000-0002-4209-2615* - 0000-0002-0327-3317**

\begin{abstract}
ÖZ
Bu çalışmanın amacı, tutuklu-hükümlü olan ve olmayan gençlerin ahlaki yargı düzeyleri ile benlik saygısı düzeylerinin karşılaştırılmasıdır. Araştırma nedensel karşılaştırmalı araştırma modeline göre yapılmıştır. Çalışma grubunu Ankara Çocuk ve Gençlik Kapalı Ceza İnfaz Kurumunda bulunan tutuklu-hükümlü olan 47 genç ile Ankara'da lise eğitimine devam eden tutuklu hükümlü olmayan 49 genç oluşturmuştur. Araştırmada "Sosyo-Demografik Bilgi Formu", "Değerlerin Belirlenmesi Testi" ve "Rosenberg Benlik Saygısı Ölçeği" kullanılmıştır. Verilerin analizinde, "Yüzde Analizi” ve "Bağımsız Gruplar İçin t Testi Analizi” uygulanmışstır. İstatistiksel analizler sonucunda, tutuklu-hükümlü gençlerin tutuklu-hükümlü olmayan gençlere göre büyük çoğunluğunun ilköğretim mezunu olduğu ve cezaevine girmeden önce çalıştıkları, kalabalık ailelerden geldikleri, anne babalarının eğitim ve sosyo-ekonomik düzeylerinin düşük olduğu, ahlaki gelişim ve benlik saygısı düzeylerinin daha düşük olduğu görülmüştür.
\end{abstract}

Anahtar Kelimeler: Ahlaki gelişim, Benlik saygısı, Cezaevi, Genç tutuklu-hükümlü

\begin{abstract}
The aim of this study is to compare the levels of moral judgment and self-esteem levels of imprisoned-convicted youth and non imprisonednon convicted youth. The research was conducted according to the causal comparative research model. The study group consisted of 47 young detainees in Ankara Children and Youth Closed Prison Institution and 49 young high school students in Ankara. "Socio-Demographic Information Form", "Determination of Values Test" and "Rosenberg Self-Esteem Scale" were used in the study. The data were analyzed by using "Percent Analysis" and "t test for Independent Groups". As a result of the statistical analysis, it was seen that the majority of the imprisoned-convicted young people were primary school graduates, worked before entering prison, came from crowded families, their parents' educational and socio-economic levels and their moral development and self-esteem levels were lower than non imprisoned-non convicted young people.
\end{abstract}

Keywords: Moral Development, Self-Esteem, Prison, Young imprisoned-convicted 


\section{Giriş}

Birleşmiş Milletler tarafından hazırlanan Çocuk Haklarına Dair Sözleşme'nin 1. maddesi, Sözleşme amaçları açısından çocuğu, 18 yaşından küçük insan olarak tanımlamaktadır (Unicef, 2002, s.1). Suç, yasanın cezalandırdığı hareket veya topluma zarar verdiği ya da tehlikeli olduğu yasa koyucu tarafından kabul edilen ve açık olarak tanımlanan eylem ve hareketlerdir. Çocuk suçluluğu, 18 yaşını doldurmamış kişilerin herhangi bir sebeple suça karışması olarak tanımlanmaktadır (Öztürk-Çopur, Ulutaşdemir ve Balsak, 2015, s.120).

Çocuk suçluluğu dünyada ve ülkemizde giderek artan bir sorundur. Türkiye İstatistik Kurumu (TÜIK) 2017 verilerine göre güvenlik birimlerine gelen veya getirilen çocuk sayısı 2013 y1lında 273.571 iken 2016 yılında bu say1 \% 23 artarak 335.242 olmuştur. 2015 yılı verilerine göre Türkiye'de cezaevlerindeki tutuklu-hükümlülerin \% 1,2'si çocuk ve gençlerden oluşmaktadır (Souverein ve diğ., 2019). Türkiye İstatistik Kurumu (TÜİK) 2017 verilerine göre ceza infaz kurumlarında çocuk hükümlülerin sayısı bir önceki yıla göre \%109,4 artarak 2.056 olurken, suç işlediği andaki yaşı çocuk yaşta olanların sayısı bir önceki yıla göre \% 28,3 artışla 11.805 olmuştur. Bunun 10.112'si 15-18 yaş aralığındaki ergenlerdir. $\mathrm{Bu}$ veriler doğrultusunda ülkemiz cezaevlerinde kalan çocuk tutuklu ve hükümlülerin büyük çoğunluğu ergenlik dönemindedir (\% 86).

Latincede olgunlaşmak anlamına gelen ergenlik (adolesan), hızlı fiziksel büyüme, cinsel gelişme ve psikososyal olgunlaşmanın gerçekleştiği, çocukluktan erişkin yaşama geçiş dönemidir (Hızel-Bülbül, 2004, s. 206). Dünya Sağlık Örgütü, ergenliği 10-19 yaş aralığ1, gençliği ise 15-24 yaş aralığı olarak kabul etmektedir. 10-24 yaş aralığındaki bireyleri ise, genç bireyler olarak kabul etmektedir (WHO, 2006, s.5). Ergenliğin tanımında sadece yaş değil, aynı zamanda sosyo-tarihsel etkilerin de göz önüne alınması gereklidir. Çocukluk ile yetişkinlik arasında biyolojik, bilişsel ve sosyo-duygusal değişimleri içeren geçiş dönemi olan ergenliğin kilit görevi yetişkinliğe hazırlıktır (Santrock, 2010, s.16). Ergenlerin homojen bir grup olmadığını göz önünde bulundurmak önemlidir. İhtiyaçları cinsiyetlerine, gelişim evrelerine, yaşam koşullarına ve çevrelerinin sosyo-ekonomik koşullarına göre değişir (WHO, 2006, s.16).

İnsanlar arasındaki ilişkiyi düzenleyen, kişilerin doğru ve yanlış davranışları ve tutumları arasındaki farkı bilip, doğru olanı değerlendirdikleri ilkeler ve yargılar sistemi olan ahlak, bireyin kişilik gelişiminin önemli öğelerinden biri olup, kişilerarası ilişkileri düzenlediğinden, toplumsal düzen ve huzur için de oldukça önemlidir. Ahlak, sosyal çevrenin de etkisiyle öğrenilen bir gelişim özelliği olarak bilinmektedir (Akçinar, Baydar ve Kağıtçıbaşı, 2018, s.154).

Ahlaki gelişim için önemli olan ahlaki muhakeme tanımını ilk yapan Piaget (1932) olmuştur, ancak gelişim bilimcilerin düşünceleri en çok Kohlberg'in çalışmalarından etkilenmiştir. Piaget'nin fikirlerinden yola çıkan ve bunları değiştiren Kohlberg, çocuklara, her birinde insan hayatının değeri gibi spesifik ahlak konusunun ele alındığı hikaye biçiminde ahlaki ikilemler sunarak ahlaki muhakemeyi değerlendirme çalışmalarına öncülük etmiştir (Bee ve Boyd, 2009, s.675). Kohlberg de Piaget gibi, kültürel sınırları aşan, doğal olan ve bilişsel temele dayanan ahlak gelişimi evreleri üzerinde durmuştur. Ancak, Piaget'nin ikili evresinin ötesine geçerek altı evreli, ergenlik ve yetişkinliğe uzanan ahlak gelişimi aşamaları belirtmiştir. Kohlberg'in araştırmalara dayanarak bulduğu ahlak gelişimi evreleri giderek yükselen bir ahlak anlayışını içeren üç düzey ve bunların her birindeki iki evre ile belirlenir (Kağıtçıbaşı ve Cemalcılar, 2014, s.222). Tablo 1'de görüldüğü gibi, Kohlberg'in kuramına göre en alt seviye olan 'gelenek öncesi' düzeyde, birey bağımllık ve ceza-itaat, bireycilik ve çıkara dayalı ilişki evrelerindedir. Bu düzeyde öncelikli olarak kendi gereksinimlerini düşünmekte olan birey, eğer ceza almayacağına inanırsa, ahlaki açıdan yanlış olan davranışları yapmaya 
çekinmeyecektir. Bir üst düzey olan kanun ve düzen, kişilerarası beklentiler ve uyum evrelerinden oluşan 'geleneksel' düzeyde, birey için toplumun tutumları ve beklentileri önemlidir. En üst seviye olan 'gelenek sonrası' düzeyde ise, sosyal anlaşma ve bireysel haklar ile evrensel ahlaki ilkeler önemlidir. Bu seviyede, bireysel hak ve özgürlüklerin önemli olduğu vurgulanmaktadır ve bu haklar toplumsal düzeni korumak ve yaşamı güvence altına almak içindir (Akçinar, Baydar ve Kağıtçıbaşı, 2018,

Tablo 1. Kohlberg'in Ahlak Gelişimi Evrelerinin Tanımlanması (Kağıtçıbaşı ve Cemalcılar, 2014, s.222).

\section{Gelenek Öncesi Düzey}

\section{Evre: İtaat ve Ceza Yönelimi}

$\mathrm{Bu}$ evrede bir davranış cezalandınlıyorsa kötü, cezalandırılmıyorsa iyidir. Cezadan kurtulmak ve yetkiye karşı tam riayet değerlidir.

\section{Evre: Saf Ç1karcı Yönelim}

Pragmatik alış-veriş kavramı (Sen bana yardım et, ben de sana ederim.), sevgi, bağl1lık ve adalet kavramı yerine geçerlidir. Çocuk ödüllendirilen davranışları yapar, cezalandırılanlardan çekinir.

\section{Geleneksel Düzey}

\section{Evre: İyi Çocuk Eğilimi}

İyi davranış, başkalarını memnun eden, onlara yardımcı olan ya da onlar tarafindan takdir edilen davranıştır.

\section{Evre: Kanun ve Düzen Eğilimi}

Doğru davranış, otoriteye saygı göstermek, kural ve yasalara uymaktır.

\section{Gelenek Üstü Düzey}

\section{Evre: Kontrat ve Yasaya Uyumluluk}

$\underline{\text { Yönelimi }}$

Doğru davranış, insan hakları ve toplum yararı gözetilerek, toplum tarafından kabul edilmiş ilkelere uygun davranıştır.

\section{Evre: Evrensel Ahlak İlkeleri Eğilimi}

Doğru ve yanlış, sosyal düzenin yasa ve kurallarıyla değil, kişinin kendi vicdanıyla ve kendi geliştirdiği ahlak ilkeleriyle tanımlanır.

Ahlaki muhakeme ile suçla ilgili davranışların ilişkili olduğu belirtilmektedir (Herzog ve Einat, 2016; Lahat, Gummerum, Mackay ve Hanoch, 2015; Romeral, Fernández ve Fraguela, 2018; Schalkwijk, Stams, Stegge, Dekker, ve Peen, 2016). Suç işlemiş ergenlerin suç işlememiş ergenlere göre ahlaki muhakeme düzeylerinin daha düşük olduğu görülmüştür (Blasi, 1980; Brugman ve Aleva, 2004; Brusten, 2002; Chandler ve Moran, 1990; Çeliköz, Seçer ve Durak, 2008; Lahat, Gummerum, Mackay ve Hanoch, 2015; Lardén, Melin, Holst, ve Långström, 2006; Nelson, Smith ve Dodd, 1990; Raaijmakers, Engels ve Van Hoof, 2005).

Kendini benimseme, onaylama, kendine değer verme, saygı duyma; kendi değerine ilişkin değerlendirme anlamına gelen benlik saygısı (Budak, 2003, s.581), çocukluğun ilk dönemlerinde yerleşir ve ergenlik ve yetişkinlik dönemlerinde de sürer; bu sürekliliğin kişide, aile içinde ve giderek toplumda geniş ölçüde olumlu etkisi vardır (Plummer, 2007, s.18). Benlik saygısı ile suç arasındaki ilişkiyi ele alan çalışmaların bazıları düşük benlik saygısı ile suç arasında ilişki olduğunu belirtmişken 
(Donnellan ve diğ., 2005; Kaplan, Johnson ve Bailey 1986; Owens 1994; Shin ve Yu 2012; Trzesniewski ve diğ., 2006) bazı çalışmalarda ise yüksek benlik saygısının neden olduğu özgüven nedeniyle suça bulaşma riskinin arttığı belirtilmiştir (Baumeister ve Smart ve Boden, 1996).

Araştırmanın Problemi

İnsanlık tarihi kadar eski olan suç kavramı ile ilişkili yapılan bilimsel çalışmalarda gençlerin dışındaki (aile, okul, arkadaş, mahalle gibi) faktörlerle gençlerin içsel (benlik, benlik saygısı, öfke, ahlaki muhakeme gibi) faktörlerinin suçla ilişkisinin olduğu görülmüştür. İlgili literatür incelendiğinde, tutuklu-hükümlü olan ve olmayan gençlerin ahlaki gelişimle birlikte benlik saygısının birlikte ele alındığı araştırmaların sınırlı sayıda olduğu görülmüş̧ür. Bu doğrultuda bu çalışmanın amacı, tutukluhükümlü olan ve olmayan gençlerin ahlaki yargı düzeyleri ile benlik saygısı düzeylerinin karşılaştırılmasıdır.

Araştırmanın Amacı

$\mathrm{Bu}$ araştırmanın amacı, tutuklu-hükümlü olan ve olmayan gençlerin ahlaki yargı düzeyleri ile benlik saygısı düzeylerinin karşılaştırılmasıdır. $\mathrm{Bu}$ temel amaç çerçevesinde aşağıdaki sorulara yanıt aranmıştır:

(i) Tutuklu-hükümlü olan ve olmayan gençlerin ahlaki yargı düzeyleri arasında anlamlı farklılık var midır?

(ii) Tutuklu-hükümlü olan ve olmayan gençlerin benlik saygısı düzeyleri arasında anlamlı farklılık var midir?

\section{Yöntem}

Araştırma Modeli

$\mathrm{Bu}$ araştırma nedensel karşılaştırmalı araştırma modeline göre yapılmıştır. Nedensel karşılaştırma araştırmaları var olan veya doğal olarak ortaya çıkmış bir durum ya da olayın nedenlerini ve bu nedenlere etki eden değişkenleri ya da bir etkinin sonuçlarını belirlemeye yönelik araştırmalardır (Büyüköztürk, Çakmak, Akgün, Karadeniz, Demirel, 2008,185).

Örneklem Grubu

Araştırmanın çalışma grubunu Ankara Çocuk ve Gençlik Kapalı Ceza İnfaz Kurumunda bulunan tutuklu-hükümlü olan 47 genç ile Ankara'da lise eğitimine devam eden tutuklu-hükümlü olmayan 49 genç oluşturmuştur. Katılımcıların hepsi erkektir. Araştırmaya katılanların ölçekleri anlayabilme, yanıtlayabilme özelliklerine sahip olmaları ve çalışmaya katılmada gönüllü olmaları şartları aranmıştır. Çalışma grubunun sayısının belirlenmesinde amaçlı örnekleme yöntemleri içerisinden ulaşılabilir örnekleme yolu kullanılmıştır (Büyüköztürk, Çakmak, Akgün, Karadeniz, Demirel, 2008).

\section{Veri Toplama Arac1}

Araştırmada tutuklu-hükümlü olan ve olmayan gençlerin bazı sosyo-demografik bilgilerini toplamak amaciyla "Sosyo-Demografik Bilgi Formu", ahlaki gelişim düzeylerini ölçmek amacıyla "Değerlerin Belirlenmesi Testi" ve benlik saygılarını ölçmek amacıyla "Rosenberg Benlik Saygısı Ölçeğiı" kullanılmıştır. 
Sosyo-Demografik Bilgi Formu, Çalışmaya katılan tutuklu-hükümlü olan ve olmayan gençlerin sosyodemografik özelliklerini tanımlamaya yönelik olarak geliştirilen "Sosyo-Demografik Bilgi Formu" uygulanmıştır. Sosyo-Demografik Bilgi Formunda cezaevindeki tutukluluk/hükümlülük durumu, yaş1, eğitim düzeyi, mesleği/işi, medeni durumu, kardeş sayısı, kardeş sırası, anne-baba eğitim düzeyi, anne-baba mesleği/işi, cezaevine girmeden önce büyüdükleri ortam, cezaevinde ziyaret edilip edilmediği ve ziyaret sıklığı hakkındaki sorular yer almaktadır.

Değerlerin Belirlenmesi Testi, Rest (1979) tarafından geliştirilen "Değerlerin Belirlenmesi Testi" Kohlberg'in Ahlaki Gelişim Kuramı'na dayanmaktadır. Değerlerin Belirlenmesi Testi'nin Türkçe’ye uyarlama ve geçerlik çalışmaları Akkoyun (1987) tarafından; güvenirlik çalışması Kaya (1993) tarafından, yapılmış ve güvenirlik katsayısı .61 olarak bulunmuştur. Değerlerin Belirlenmesi Testi'nde bir ikilemi yansıtan altı öykü ve her öykü ile ilgili 12 cümle verilmektedir. Katılımcılardan verilen 12 düşünceyi içeren cümleleri 5'li Likert Ölçeği üzerinde önem sırasına göre işaretlemeleri istenmektedir. On iki düşünce içeren cümleden, en önemli 4 tanesini yine önem sırasına göre derecelemeleri istenmektedir. Testin puanlanması sonucunda 2, 3, 4, 5A, 5B ve 6. Evrelerdeki akıl yürütme özelliklerinin yanı sıra, 5. ve 6. evre yargılarına verilen ağırlığ 1 temsil eden $P$ puanı da ortaya çıkmaktadır. İkinci evre puanları, somut ve bireyselciliğin ahlaki kararlarda önemli olduğu evreyi, 3 . evre puanları, toplum tarafindan kabul edilmenin ahlaki kararlarda önemli olduğu evreyi, 4. evre puanları, ahlaki kararlar alınırken yasanın üstünde başka bir gücün kabul edilmediği evreyi, 5A puanları, sosyal yapının, ahlaki temeli hakkındaki kaygıların öne çıtığı evreyi, 5B puanları, sezgisel insancıllığın ahlaki kararlarda önemli olduğu evreyi, 6. evre puanları, ideal sosyal işbirliği prensiplerinin itibar gördüğü ahlak anlayışını, A puanları, gelenekleri, keyfiliği ve toplumun sömürülmesi yoluyla ulaşılan refahı reddeden tutumu belirlemektedir. P puanı, katılımcının gelenek ötesi ahlaki yargı evrelerine verdiği ağırlı̆̆ göstermektedir. M puanı, katılımcının anlamsız ve gösterişli maddelere verilen değeri ifade eden puandır. M puanı herhangi bir evreyi temsil etmez. M puanı sekiz ya da daha yukarı olduğu durumlarda cevap kağıdı iptal edilmektedir. (Bayer, 2008; Durak-Demirhan, 2007).

Rosenberg Benlik Saygısı Ölçeği, Rosenberg tarafından 1965 yılında geliştirilmiştir. Rosenberg Benlik Saygısı Ölçeği, dörtlü likert tipindedir ve toplam 63 sorudan oluşmaktadır. Rosenberg Benlik Saygısı Ölçeğinin Türkçe formunun geçerlik ve güvenirlik çalışması Çuhadaroğlu (1986) tarafından yapılmıştır. Geçerliği yüksek olup test tekrar test korelasyonu 0.82-0.88 arasında değişmektedir. Cronbach'ın alfa değişkeni 0.77 ile 0.88 arasında değişmektedir. Rosenberg Benlik Saygısı Ölçeği puanları 0-30 arasında değişir ve bu ölçekten alınabilecek en yüksek puan 30'dur.

Verilerin Analizi

Verilerin analizinde, çalışmada kullanılan Sosyo-Demografik Bilgi Formuna ait verilerin analizinde yüzde analizi; ve Değerlerin Belirlenmesi Testi ile Rosenberg Benlik Saygısı Ölçeklerine ilişkin puan ortalamaları arasında anlamlı bir fark olup olmadığını belirlemek için "Bağımsız Gruplar İçin T Test Analizi” kullanılmıştır. Sonuçlar yorumlanırken anlamlılık düzeyi olarak 0,01 kullanılmıştır.

\section{Bulgular ve Yorumlar}

Bu bölümde tutuklu-hükümlü olan ve olmayan gençlerin sosyo-demografik özellikleri, ahlaki gelişim düzeyleri ve benlik saygıları ile ilgili bulgular ve yorumlar yer almaktadır. 
Tablo 2. Tutuklu-Hükümlü Olan ve Olmayan Gençlerin Sosyo-Demografik Özelikleri

\begin{tabular}{|c|c|c|c|c|c|c|}
\hline $\begin{array}{l}\text { Tutuklu-Hükümlü Olan Gençlerin } \\
\text { Durumu }\end{array}$ & $\mathbf{n}$ & $\%$ & $\begin{array}{l}\text { Tutuklu-Hükümlü } \\
\text { Gençlerin Durumu }\end{array}$ & Olmayan & $\mathbf{n}$ & $\%$ \\
\hline Tutuklu & 29 & 61,7 & Öğrenci & & 49 & 100 \\
\hline Hükmen Tutuklu & 9 & 19,1 & & & & \\
\hline Hükümlü & 9 & 19,1 & & & & \\
\hline $\begin{array}{l}\text { Tutuklu-Hükümlü Olan Gençlerin } \\
\text { Yaşı }\end{array}$ & $\mathbf{n}$ & $\%$ & $\begin{array}{l}\text { Tutuklu-Hükümlü } \\
\text { Gençlerin Yaşı }\end{array}$ & Olmayan & $\mathbf{n}$ & $\%$ \\
\hline 15 & 10 & 21,3 & 15 & & 11 & 22,4 \\
\hline 16 & 9 & 19,1 & 16 & & 10 & 20,4 \\
\hline 17 & 10 & 21,3 & 17 & & 11 & 22,4 \\
\hline 18 & 18 & 38,3 & 18 & & 17 & 35 \\
\hline $\begin{array}{l}\text { Tutuklu-Hükümlü Olan Gençlerin } \\
\text { Eğitim Düzeyi }\end{array}$ & $\mathbf{n}$ & $\%$ & $\begin{array}{l}\text { Tutuklu-Hükümlü } \\
\text { Gençlerin Eğitim Düzeyi }\end{array}$ & Olmayan & $\mathbf{n}$ & $\%$ \\
\hline Okuryazar & 13 & 17,6 & Lise & & 49 & 100 \\
\hline İlköğretim & 33 & 70,2 & & & & \\
\hline Lise & 1 & 2,1 & & & & \\
\hline $\begin{array}{l}\text { Tutuklu-Hükümlü Olan Gençlerin } \\
\text { Meslek/İşleri }\end{array}$ & $\mathbf{n}$ & $\%$ & $\begin{array}{l}\text { Tutuklu-Hükümlü } \\
\text { Gençlerin Meslek/İşleri }\end{array}$ & Olmayan & $\mathbf{n}$ & $\%$ \\
\hline Öğrenci & 11 & 23,4 & Öğrenci & & 49 & 100 \\
\hline Gelir getiren işi var & 26 & 55,3 & & & & \\
\hline İşsiz & 10 & 21,3 & & & & \\
\hline $\begin{array}{l}\text { Tutuklu-Hükümlü Olan Gençlerin } \\
\text { Medeni Durumu }\end{array}$ & $\mathbf{n}$ & $\%$ & $\begin{array}{l}\text { Tutuklu-Hükümlü } \\
\text { Gençlerin Medeni Durum }\end{array}$ & Olmayan & $\mathbf{n}$ & $\%$ \\
\hline Bekar & 37 & 78,7 & Bekar & & 49 & 100 \\
\hline Sözlü-Nişanlı & 9 & 19,1 & & & & \\
\hline Evli & 1 & 2,1 & & & & \\
\hline $\begin{array}{l}\text { Tutuklu-Hükümlü Olan Gençlerin } \\
\text { Kardeş Sayısı }\end{array}$ & $\mathbf{n}$ & $\%$ & $\begin{array}{l}\text { Tutuklu-Hükümlü } \\
\text { Gençlerin Kardeş Sayısı }\end{array}$ & Olmayan & $\mathbf{n}$ & $\%$ \\
\hline $1-3$ & 31 & 65,9 & $1-3$ & & 32 & 65,3 \\
\hline
\end{tabular}




\begin{tabular}{|c|c|c|c|c|c|}
\hline $4-6$ & 11 & 23,4 & 4 & 17 & 34,7 \\
\hline $7-10$ & 5 & 10,63 & & & \\
\hline $\begin{array}{l}\text { Tutuklu-Hükümlü Olan Gençlerin } \\
\text { Kardeş Sırası }\end{array}$ & $\mathbf{n}$ & $\%$ & $\begin{array}{ll}\text { Tutuklu-Hükümlü } & \text { Olmayan } \\
\text { Gençlerin Kardeş Sırası } & \end{array}$ & $\mathbf{n}$ & $\%$ \\
\hline $1-2$ & 27 & 57,4 & $1-2$ & 30 & 61,2 \\
\hline $3-5$ & 15 & 31,9 & $3-4$ & 19 & 38,8 \\
\hline $6-7$ & 5 & 10,6 & & & \\
\hline $\begin{array}{l}\text { Tutuklu-Hükümlü Olan Gençlerin } \\
\text { Anne Babaları }\end{array}$ & $\mathbf{n}$ & $\%$ & $\begin{array}{l}\text { Tutuklu-Hükümlü } \text { Olmayan } \\
\text { Gençlerin Anne ve Babaları }\end{array}$ & $\mathbf{n}$ & $\%$ \\
\hline Anne ve baba hayatta & 38 & 80,9 & Anne ve baba hayatta & 45 & 92 \\
\hline Anne yaşamıyor & 2 & 4,3 & Anne yaşamıyor & 1 & 2 \\
\hline Baba yaşamıyor & 6 & 12,8 & Baba yaşamıyor & 1 & 2 \\
\hline Anne ve baba yaşamıyor & 1 & 2,1 & Anne ve baba yaşamıyor & 2 & 4 \\
\hline $\begin{array}{l}\text { Tutuklu-Hükümlü Olan Gençlerin } \\
\text { Anne Babalarının Medeni Durum }\end{array}$ & $\mathbf{n}$ & $\%$ & $\begin{array}{l}\text { Tutuklu-Hükümlü } \\
\text { Gençlerin Anne } \\
\text { Medeni Durum }\end{array}$ & $\mathbf{n}$ & $\%$ \\
\hline
\end{tabular}

\begin{tabular}{lcclcc}
\hline Evli & 40 & 82 & Evli & 45 & 92 \\
Boşanmış & 7 & 15 & Boşanmış & 4 & 8
\end{tabular}

\begin{tabular}{|c|c|c|c|c|c|c|}
\hline $\begin{array}{l}\text { Tutuklu-Hükümlü Olan Gençlerin } \\
\text { Annelerinin Eğitim Düzeyi }\end{array}$ & $\mathbf{n}$ & $\%$ & $\begin{array}{l}\text { Tutuklu-Hükümlü } \\
\text { Gençlerin Annelerinin } \\
\text { Düzeyi }\end{array}$ & $\begin{array}{r}\text { Olmayan } \\
\text { Eğitim }\end{array}$ & $\mathbf{n}$ & $\%$ \\
\hline Okuryazar Değil & 14 & 29,8 & Okuryazar Değil & & 1 & 2 \\
\hline Okuryazar & 6 & 12,8 & Okuryazar & & 2 & 4 \\
\hline İlköğretim & 25 & 53,2 & İlköğretim & & 11 & 22,5 \\
\hline Lise & 1 & 2,1 & Lise & & 23 & 47 \\
\hline Üniversite & 1 & 2,1 & Üniversite & & 12 & 24,5 \\
\hline $\begin{array}{l}\text { Tutuklu-Hükümlü Olan Gençlerin } \\
\text { Annelerinin Mesleği/işi }\end{array}$ & $\mathbf{n}$ & $\%$ & $\begin{array}{l}\text { Tutuklu-Hükümlü } \\
\text { Gençlerin Annelerinin Mc }\end{array}$ & $\begin{array}{l}\text { Olmayan } \\
\text { esleği/işi }\end{array}$ & $\mathbf{n}$ & $\%$ \\
\hline Ev hanımı & 39 & 83 & Ev hanımı & & 25 & 51 \\
\hline Gelir getiren işi var & 5 & 10,6 & Gelir getiren işi var & & 24 & 49 \\
\hline
\end{tabular}




\begin{tabular}{|c|c|c|c|c|c|c|}
\hline Tutuklu-Hükümlü Olan Gençlerin & $\mathbf{n}$ & $\%$ & Tutuklu-Hükümlü & Olmayan & $\mathbf{n}$ & \\
\hline Babalarının Eğitim Düzeyi & & & $\begin{array}{l}\text { Gençlerin Babalarının } \\
\text { Düzeyi }\end{array}$ & Eğitim & & $\%$ \\
\hline Okuryazar Değil & 9 & 19,1 & Okuryazar & & 2 & 4,1 \\
\hline Okuryazar & 6 & 12,8 & İlköğretim & & 15 & 30,6 \\
\hline İlköğretim & 29 & 61,7 & Lise & & 25 & 51,1 \\
\hline Lise & 2 & 4,3 & Üniversite & & 7 & 14,2 \\
\hline Üniversite & 1 & 2,1 & & & & \\
\hline $\begin{array}{l}\text { Tutuklu-Hükümlü Olan Gençlerin } \\
\text { Babalarının Mesleği/işi }\end{array}$ & $\mathbf{n}$ & $\%$ & $\begin{array}{l}\text { Tutuklu-Hükümlü } \\
\text { Gençlerin Babalarının Me }\end{array}$ & $\begin{array}{l}\text { Olmayan } \\
\text { sleği/işi }\end{array}$ & $\mathbf{n}$ & $\%$ \\
\hline Gelir getiren işi var & 39 & 83 & Gelir getiren işi var & & 47 & 95,9 \\
\hline İşsiz & 6 & 12,8 & İşsiz & & 2 & 4,1 \\
\hline $\begin{array}{l}\text { Tutuklu-Hükümlü } \text { Olan Gençlerin } \\
\text { Cezaevi Öncesi Büyüdükleri }\end{array}$ & $\mathbf{n}$ & $\%$ & & & & \\
\hline
\end{tabular}

\begin{tabular}{lcc}
\hline Anne ile & 1 & 2,1 \\
Baba ile & 4 & 8,5 \\
Anne /baba ile & 39 & 83 \\
Sosyal Hizmetler Kurumunda & 3 & 6,4 \\
\hline Tutuklu-Hükümlü Olan Gençlerin & $\mathbf{n}$ & $\mathbf{\%}$ \\
Ziyaret Durumu & & \\
\hline Ziyaretine gelen var & 42 & 89,4 \\
Ziyaretine gelen yok & 5 & 10,6 \\
\hline Tutuklu-Hükümlü Olan Gençlerin & $\mathbf{n}$ & $\mathbf{\%}$ \\
Ziyaret Sıklıkları & & \\
\hline Her hafta geliyor & 23 & 48,9 \\
Ayda bir kez geliyor & 5 & 21,3 \\
Ayda iki kez geliyor & 10 & 10,6 \\
İki-üç ayda bir kez geliyor & 2 & 4,3 \\
Altı ayda bir kez geliyor & 2 & 4,3 \\
\hline
\end{tabular}


Tutuklu-Hükümlü olan gençlerin sosyo-demografik özellikleri incelendiğinde (Tablo 2), \% 61,7'sinin tutuklu, \% 38,3'ünün 18 yaşında, \% 70,2'sinin ilköğretim mezunu, \% 55,3'ünün gelir getiren işi olduğu, \% 78,7'sinin bekar, \% 65,9'unun 1-3 kardeşi olduğu, 57,4'ünün ilk iki çocuktan biri olduğu, $\%$ 80,9'unun anne babasının hayatta olduğu, \% 80,9'unun anne babasının evli olduğu, \% 53,2'sinin annesinin ilköğretim mezunu, \% 83'ünün ev hanımı olduğu, \% 61,7'sinin babasının ilköğretim mezunu, \% 83'ünün gelir getiren işi olduğu, \% 89,4'ünün cezaevine ziyaretine gelen yakınlarının olduğu, \% 48,9'unun ziyaretine her hafta gelindiği öğrenilmiştir. Tutuklu-Hükümlü olmayan gençlerin sosyo-demografik özellikleri incelendiğinde, tümünün lise öğrencisi ve bekar olduğu, \% 35'inin 18 yaşında, \% 65,3'ünün 1-3 kardeşi olduğu, \% 61,2'sinin ilk iki çocuktan biri olduğu, \% 92'sinin anne babasının hayatta olduğu, \% 24,5'inin annesinin ilköğretim mezunu, \% 51'inin ev hanımı olduğu, \% 51,1’inin babasının lise mezunu, \% 95,9'unun gelir getiren işi olduğu öğrenilmiştir.

Tablo 3'te tutuklu-hükümlü olan ve olmayan gençlerin Değerlerin Belirlenmesi Testi ve Rosenberg Benlik Saygısı Ölçeğinden aldıkları puanlar arasında fark olup olmadığını değerlendirmek amacıyla uygulanan Bağımsız Gruplar İçin $T$ Testi Analizi” sonuçları verilmiştir. 
Tablo 3. Tutuklu-hükümlü Olan ve Olmayan Gençlerin Değerlerin Belirlenmesi Testi ve Rosenberg Benlik Saygısı Ölçeği Puanlarına İlişkin Bağımsız Gruplar İçin T Testi

\begin{tabular}{|c|c|c|c|c|c|c|c|}
\hline Değişkenler & $\begin{array}{l}\text { Tutuklu- } \\
\text { Hükümlü }\end{array}$ & $\mathbf{N}$ & Ortalama & $\mathbf{S}$ & $\mathbf{t}$ & Sd & $\mathbf{p}$ \\
\hline \multirow[t]{2}{*}{ Evre 2} & Evet & 47 & 2,47 & 1,23 & $-3,696$ & 89,362 &, $000 * *$ \\
\hline & Hayır & 49 & 3,55 & 1,62 & & & \\
\hline \multirow[t]{2}{*}{ Evre 3} & Evet & 47 & 17,80 & 5,85 & 3,351 & 68,376 &, $001 * *$ \\
\hline & Hayır & 49 & 21 & 3,03 & & & \\
\hline \multirow[t]{2}{*}{ Evre 4} & Evet & 47 & 11,06 & 2,75 & $-8,815$ & 94 &, $000 * *$ \\
\hline & Hayır & 49 & 15,53 & 2,20 & & & \\
\hline \multirow[t]{2}{*}{ Evre 5A } & Evet & 47 & 5,47 & 1,90 & $-3,694$ & 77,165 &, $000 * *$ \\
\hline & Hayır & 49 & 7,49 & 3,30 & & & \\
\hline \multirow[t]{2}{*}{ Evre 5B } & Evet & 47 & 1,55 & ,65 & $-1,125$ & 74,340 & ,264 \\
\hline & Hayır & 49 & 1,78 & 1,21 & & & \\
\hline \multirow[t]{2}{*}{ Madde A } & Evet & 47 & 3,53 & 1,97 &,- 205 & 94 & ,838 \\
\hline & Hayır & 49 & 3,61 & 1,86 & & & \\
\hline \multirow[t]{2}{*}{ Madde M } & Evet & 47 & 2,19 & 1,62 &, 083 & $-1,619$ & 94 \\
\hline & Hayır & 49 & 2,84 & 2,22 & & & \\
\hline \multirow[t]{2}{*}{ P Puanı } & Evet & 47 & 8,28 & 2,47 &, 560 & 94 & ,809 \\
\hline & Hayır & 49 & 8,16 & 2,11 & & & \\
\hline \multirow[t]{2}{*}{ Benlik Saygısı } & Evet & 47 & 18,74 & 3,82 & $-5,949$ & 94 &, $000 * *$ \\
\hline & Hayır & 49 & 22,55 & 2,29 & & & \\
\hline
\end{tabular}

$\mathrm{p}<0,01^{* *}$

Tablo 3 incelendiğinde, tutuklu-hükümlü olan ve olmayan gençlerin ahlaki gelişim düzeyleri ile benlik saygısı düzeyleri arasında $(\mathrm{p}<0,01)$ anlamlı farklılıklar tespit edilmiştir. Ahlaki gelişim düzeyini ölçen Değerlerin Belirlenmesi Testi Evre 2, Evre 3, Evre 4 ve Evre 5 Puanları ile Rosenberg Benlik Saygıs1 Puanları arasında farklılıklar ortaya çıkmıştır. Tutuklu-hükümlü olmayan gençlerin Evre $2(\overline{\mathrm{X}}=3,55)$, Evre $3(\overline{\mathrm{X}}=21)$, Evre $4(\overline{\mathrm{X}}=15,53)$ ve Evre $5 \mathrm{~A}(\overline{\mathrm{X}}=7,49)$ puanlarının tutuklu-hükümlü gençlerin Evre 2 $(\overline{\mathrm{X}}=2,47)$, Evre $3(\overline{\mathrm{X}}=17,80)$, Evre $4(\overline{\mathrm{X}}=11,06)$ ve Evre 5 A $(\overline{\mathrm{X}}=5,47)$ puanlarından daha yüksek olduğu görülmüBu çalışmada tutuklu-hükümlü olan ve olmayan gençlerin sosyo-demografik 
özellikleri incelenmiş, ahlaki yargı düzeyleri ile benlik saygısı düzeyleri karşılaştırılmıştır. Yapılan istatistiksel analizler sonucunda, ahlaki gelişim düzeyini ölçen "Değerlerin Belirlenmesi Testi” Evre 2, Evre 3, Evre 4 ve Evre 5 Puanları ile "Rosenberg Benlik Saygısı Ölçeği” puanları arasında farklılıklar ortaya çıkmıştır. Tutuklu-hükümlü olmayan gençlerin puanlarının tutuklu-hükümlü olan gençlerden daha yüksek olduğu görülmüştür.

\section{Tartışma ve Sonuç}

Bu çalışmada tutuklu-hükümlü olan ve olmayan gençlerin sosyo-demografik özellikleri incelenmiş, ahlaki yargı düzeyleri ile benlik saygısı düzeyleri karşılaştırılmıştır. Yapılan istatistiksel analizler sonucunda, ahlaki gelişim düzeyini ölçen "Değerlerin Belirlenmesi Testi" Evre 2, Evre 3, Evre 4 ve Evre 5 Puanları ile "Rosenberg Benlik Saygısı Ölçeği” puanları arasında farklılıklar ortaya çıkmıştır. Tutuklu-hükümlü olmayan gençlerin puanlarının tutuklu-hükümlü olan gençlerden daha yüksek olduğu görülmüsşür.

Çocuk ve ergenlerde görülen suç davranışları ile ilgili yapılan araştırmalarda, doğum öncesi dönemden başlayarak bütün yaşam süresi boyunca, kişisel, biyolojik, genetik ve toplumsal faktörlerin karmaşık etkileşimlerinin sonucu ortaya çıktığı bilinmektedir (Ögel, 2014). Yapılan çalışmalarda okul yıllarında sürdürülen yoğun iş yaşamının çocukların davranışları üzerinde olumsuz etki yarattığını ve suç davranışını artırdığı bilinmektedir (Korkmaz ve Erden, 2010). Eğitim düzeyi arttıkça suç işleme ve tutuklanma ihtimalinin belirgin bir şekilde azaldığı görülmektedir (Ögel, 2014). Anne-babaların eğitim düzeyleri ve sosyo-ekonomik düzeyleri arttıkça çocukların suça karışma olasılıklarının azaldığını bildiren çalışmalar mevcuttur (Korkmaz ve Erden, 2010). Bu çalışmada da ilgili literatürle uyumlu olarak tutuklu-hükümlü gençlerin büyük çoğunluğunun ilköğretim mezunu olduğu ve cezaevine girmeden önce çalıştığı belirlenmiştir. Ayrıca tutuklu-hükümlü olan gençlerin bir kısmının sözlünişanlı olduğu, kalabalık ailelerden geldikleri, anne babalarının eğitim ve sosyo-ekonomik düzeylerinin daha düşük olduğu görülmüştür.

Suç işlemiş ergenlerin suç işlememiş ergenlere göre ahlaki muhakeme düzeylerinin daha düşük olduğu çeşitli çalışma sonuçlarında ortaya çıkmıştır (Blasi, 1980; Brugman ve Aleva, 2004; Brusten, 2002; Chandler ve Moran, 1990; Çeliköz, Seçer ve Durak, 2008; Lahat, Gummerum, Mackay ve Hanoch, 2015; Lardén, Melin, Holst, ve Långström, 2006; Nelson, Smith ve Dodd, 1990; Raaijmakers, Engels ve Van Hoof, 2005). Bu çalışmanın sonuçlarının ilgili literatürle uyumlu olduğu görülmüş̧ür. $\mathrm{Bu}$ çalışmada ahlaki gelişim düzeylerini ölçmek için kullanılan "Değerlerin Belirlenmesi Testi"nde ölçülen ikinci evre puanları, somut ve bireyselciliğin ahlaki kararlarda önemli olduğu evreyi, 3. evre puanları, toplum tarafından kabul edilmenin ahlaki kararlarda önemli olduğu evreyi, 4. evre puanları, ahlaki kararlar alınırken yasanın üstünde başka bir gücün kabul edilmediği evreyi, 5A puanları, sosyal yapının, ahlaki temeli hakkındaki kaygıların öne çıktığı evreyi göstermektedir. Tutuklu-hükümlü olmayan gençlerin tutuklu-hükümlü olan gençlere göre bu özelliklere daha fazla sahip olduğu görülmektedir.

Ahlaki muhakeme düzeyi yüksek olan çocuk ve ergenlerin toplum yanlısı davranışlarının daha yüksek olduğu, ahlaki muhakeme düzeyi düşük olanların ise anti-sosyal davranışları daha fazladır. Kohlberg'e göre kişinin ahlaki muhakeme düzeyi ne kadar yüksekse davranışları ile arasındaki bağ da o denli güçlüdür. Dördüncü veya beşinci muhakeme düzeylerine sahip olan gençlerin kendi kurallarını ve akıllarını izleme eğilimlerinin muhakeme düzeyleri daha düşük olan çocuk ve gençlere oranla daha yüksektir (Bee ve Boyd, 2009).

Benlik saygısı ile suç arasındaki ilişkiyi ele alan çalışmaların bazıları düşük benlik saygısı ile suç arasında ilişki olduğunu belirtmişken (Donnellan ve diğ., 2005; Kaplan, Johnson ve Bailey 1986; 
Owens 1994; Shin ve Yu 2012; Trzesniewski ve diğ., 2006) bazı çalışmalarda ise yüksek benlik saygısının neden olduğu özgüven nedeniyle suça bulaşma riskinin arttığı belirtilmiştir (Baumeister ve Smart ve Boden, 1996). Bu çalışmadan elde edilen sonuçlar, düşük benlik saygısı ile suç arasında ilişki olduğunu bildiren çalışmalarla uyumlu çıkmıştır. Düşük benlik saygısı ile suç arasındaki ilişkiyi ilk araştıran araştırmacılardan Kaplan'a göre bazı ergenlerin suç işleme nedenleri arasında benlik saygısında azalma ve benliğin aşağılanması yer almaktadır (Cheng, 2014). Bireylerin suça karışmış gruplarla olan ilişkilerinin devam etmesi ve bu grupta bulunan bireyler ile birlikte suç işlemeleri, aynı şekilde onların benlik oluşturma süreci ile alakalı bir durumdur. Bu gruplar, ergenlerin özgüven ekseninde yeni bir benlik oluşturma süreçlerinde temel bir rol oynamaktadır. Ergenlerin bu gruplar içerisinde yer alma isteklerinin veya onlara katılma nedenlerinin temel bir amacı, aile ve okul ortamlarında geleneksel beklentilere ulaşma konusunda yaşadıkları başarısızlıkların, gerilimlerin ve bunun yarattığı aşağılanma duygusunun giderilmesi yönündeki beklenti oluşturmaktadır (Kızmaz, 2006). Tutuklu-hükümlü olan gençlerin benlik saygısı düzeyinde azalmada, suç işleme, yargılanma, cezaevine girme ve cezaevinde bulunma gibi nedenlerin rol oynayabileceği de düşünülmektedir.

Benlik saygısı ve ahlaki muhakeme, kişisel, duygusal ve sosyal yaşamda çok önemli rollere sahip iki bileşendir. Benlik saygısı, düşünce, duygu, davranış, akıl-ruh sağlığı, kişinin aldığı kararlar, sosyal ilişkiler, başarı, öz-güven, başkalarına güven gibi konularda çok önemli bir kavram olup tüm yaşamda etkili bir faktördür. Ahlaki muhakeme, düşüncelerde, alınan kararlarda ve eylemlerde önemli bir dayanak noktasıdır. Çocuğun içine doğduğu sosyal çevreden başlayarak sosyal ve akademik çevrelerde bu iki faktörün öğretilmesi için onlara küçük yaşlardan itibaren bu konularda eğitimler verilmesi gerektiği düşünülmektedir.

Suç ile benlik saygısı ve ahlaki muhakeme arasındaki ilişki, bu çalışma dâhil olmak üzere çok sayıda çalışma ile ortaya konmuştur. Buradan hareketle, benlik saygısı düşük olan çocuk ve gençlerin tespit edilerek benlik saygılarının artırılmasına yönelik müdahalelerin yapılmasının, alkol, madde, internet, bilgisayar, akıllı telefon gibi bağımlılıkların, suç ve şiddet gibi davranışların azaltılması bakımından önemli olduğu düşünülmektedir. Ahlaki muhakeme düzeyi düşük olan çocuk ve gençlerin tespit edilerek, "doğru-yanlış" gibi karar verme becerilerinin artırılması, ahlaki ve toplumsal kurallar ve ahlaki ikilemler hakkında bilgilendirmelerin yapılmasının suç davranışlarının önlenmesinde olumlu katkılar sağlayacağı düşünülmektedir.

Suçun çok sayıda faktörden etkilendiği bilinmektedir. Çocuk ve gençlerin iç dünyalarında yer alan benlik saygısı ve ahlaki muhakeme gibi süreçlerin geliştirilmesinin çocuk ve ergenlerin suçtan uzak tutulmasında olumsuz dışsal faktörlerle baş edebilmesinde önemli olduğu düşünülmektedir. Suça bulaşmış ve cezaevinde olan gençlere yönelik yapılacak benlik saygısı ve ahlaki muhakeme müdahale programlarının, cezaevinde yaşanabilecek olumsuz davranışların ve cezaevinden tahliye olduktan sonra yeniden suç işleyip cezaevine girme gibi durumların azaltılmasında önemli olduğu düşünülmektedir. 


\section{Kaynakça}

Akçinar, B., Baydar, N. ve Kağıtçıbaşı, Ç. (2018). Erken Ergenlikte Ahlak Gelişimi: Bir Müdahale Araştırması. Eğitimde Kuram ve Uygulama, 14(2), 153-169. doi:10.17244/eku.322365

Baumeister, R. F., Smart, L., Boden, J. M. (1996). Relation of Threatened Egotism to Violence and Aggression: The Dark Side of High Self-Esteem. Psychological Review, 103(1), 5-33.

Bayer, F. (2008). Çocuk Eğitim Evleri ve Ankara Çocuk ve Gençlik Kapalı Ceza İnfaz Kurumu’nda Kalmakta Olan Ergenlerin Ahlaki Yargı Düzeylerinin İncelenmesi (Yayınlanmamış Yüksek Lisans Tezi). Gazi Üniversitesi/Eğitim Bilimleri Enstitüsü.

Bee, H. ve Boyd, D. (2009). Çocuk gelişim psikolojisi. O. Gündüz (Çev.). İstanbul: Kaknüs.

Blasi, A. (1980). Bridging Moral Cognition and Moral Action: A Critical Review of the Literatüre. Psychological Bulletin, 88, 1-45.

Brugman, D., Aleva, A. E. (2004). Developmental Delay or Regression in Moral Reasoning by Juvenile Delinquents? Journal of Moral Education, 33(3), 321-338. doi: $10.1080 / 0305724042000733082$

Brusten, C. M. (2002). Investigation of the Moral Reasoning of Offending and Non-Offending Adolescents Using the Sociomoral Reflection Measure-Short Form (Unpublished Doctoral Thesis). University of Oxford.

Budak, S. (2003). Psikoloji Sözlüğü. Ankara: Bilim Sanat.

Büyüköztürk, Ş. (2014). Sosyal Bilimler İçin Veri Analizi El Kitabı. Ankara: Pegem Akademi.

Büyüköztürk, Ş., Çakmak, E., Akgün, Ö. E., Karadeniz, Ş. ve Demirel, F. (2008). Bilimsel Araştırma Yöntemleri (2. bask1). Ankara: Pegem A.

Chandler, M., Moran, T. (1990). Psychopathy and Moral Development: A Comparative Study of Delinquent and Nondelinquent Youth. Development and Psychopathology, 2(3), 227-246. doi: 10.1017/ S0954579400000742

Cheng, C. (2014). The Predictive Effects of Self-Esteem, Moral Self, and Moral Reasoning on Delinquent Behaviors of Hong Kong Young People. International Journal of Criminology and Sociology, 3, 133-145.

Çeliköz, N., Seçer, Z. ve Durak, T. (2008). Suç İşleyen ve İşlemeyen Çocukların Düşünme Becerileri ve Ahlaki Yargılarının İncelenmesi. Selçuk Üniversitesi Ahmet Keleşoğlu Eğitim Fakültesi Dergisi, $25,335-350$.

Çuhadaroğlu F. (1986). Adolesanlarda Benlik Saygısı (Yayınlanmamış Uzmanlık Tezi). Hacettepe Üniversitesi/Tıp Fakülesi.

Durak-Demirhan, T. (2007). Yoğun Düşünme Eğitimi Programının Suçlu Çocuklarının Ahlaki Yargılarına Etkisinin İncelenmesi (Yayınlanmamış Yüksek Lisans Tezi). Selçuk Üniversitesi/Sosyal Bilimler Enstitüsü. 
Donnellan, M. B., Trzesniewski, K. H., Robins, R. W., Moffitt, T. E., Caspi, A. (2005). Low SelfEsteem is Related to Aggression, Antisocial Behavior, and Delinquency. Psychological Science, 16, $328-335$.

Herzog, S., Einat, T. (2016). Moral Judgment, Crime Seriousness, and the Relations Between Them: An Exploratory Study. Crime \& Delinquency, 62(4), 470-500. doi: 10.1177/0011128712466889

Hızel-Bülbül, S. (2004). Ergen Etiği. STED, 13 (6), 206-210.

Kağıtçıbaşı, Ç. ve Cemalcılar, Z. (2014). Dünden Bugüne İnsan ve İnsanlar: Sosyal Psikolojiye Giriş. İstanbul: Evrim.

Kaplan, H. B., Johnson, R. J., Bailey, C. A. (1986). Self-Rejection and the Explanation of Deviance: Refinement and Elaboration of a Latent Structure. Social Psychology Quarterly, 49(2):101-128. http://dx.doi.org/10.2307/2786723

Karasar, N. (2008). Bilimsel Araştırma Yöntemi (17.Baskı). Ankara: Nobel.

Kızmaz, Z. (2006). Kriminolojide Yeni Yönelimler: Bütünleşik (Integrated) Suç Kuramları - II, Fırat Üniversitesi Sosyal Bilimler Dergisi, 16, 1, 305-335.

Lahat, A., Gummerum, M., Mackay, L., Hanoch, Y. (2015). Cognitive Processing of Moral and Social Judgements: A Comparison of Offenders, Students, and Control Participants. The Quarterly Journal of Experimental Psychology, 68(2), 350-362. doi: 10.1080/17470218.2014.944918

Lardén, M., Melin, L., Holst, U., Långström, N. (2006). Moral Judgement, Cognitive Distortions and Empathy in İncarcerated Delinquent and Community Control Adolescents. Psychology, Crime \& Law, 12(5), 453-462. doi:10.1080/10683160500036855

Nelson, J. R., Smith, J. J., Dodd, J. (1990). The Moral Reasoning of Juvenile Delinquents: A Metaanalysis, Journal of Abnormal Child Psychology, 18, 231-239.

Owens, T.J. (1994). Two Dimensions of Self-Esteem: Reciprocal Effects of Positive Self-Worth and Self-Deprecation on Adolescent Problems. American Sociological Review, 59(3):391407.http://dx.doi.org/10.2307/2095940

Ögel, K. (2014). Çocuk, Suç ve Bireyselleştirilmiş İyileştirme. Çocuklar için Adalet Projesi, Ankara.

Öztürk-Çopur, E., Ulutaşdemir, N., Balsak, H.(2015). Çocuk ve Suç. Hacettepe University Faculty of Health Sciences Journal, 1, 120-124.

Plummer, D.M. (2007). Benlik Saygısı Çocuklarda Nasıl Geliştirilir? E. Aksay (Çev.). İstanbul: Sistem.

Raaijmakers, Q. A. W., Engels, R.,Van Hoof, A. (2005). Delinquency and Moral Reasoning in Adolescence and Young Adulthood. International Journal of Behavioral Development, 29(3), 247-258. doi: $10.1080 / 01650250544000035$

Romeral, L.F., Fernández, J.S., Fraguela, J.A.G. (2018). Moral Reasoning in Adolescent Offenders: A Meta-Analytic Review. Psicothema, 30 (3), 289-294.

Santrock, J. W. (2008). Adolescense (12th ed.). New York: McGraw-Hill. 
Schalkwijk, F., Jan Stams, G., Stegge, H., Dekker, J., Peen, J. (2016). The Conscience as a Regulatory Function: Empathy, Shame, Pride, Guilt, and Moral Orientation in Delinquent Adolescents. International Journal of Offender Therapy and Comparative Criminology, 60(6), 675-693. doi: $10.1177 / 0306624 X 14561830$

Shin, H. J., Yu K. (2012). Connectedness of Korean Adolescents: Profiles and Influencing Factors. Asia Pacific Educational Review, 13(4):593-605.

Souverein, F. ve diğ. (2019). Overview of European Forensic Youth Care: Towards an Integrative Mission for Prevention and Intervention Strategies for Juvenile Offenders. Child and Adolescent Psychiatry and Mental Health, 13, 1-6. Doi: 10.1186/s13034-019-0265-4

Türkiye İstatistik Kurumu (TÜIK). Ceza infaz kurumu istatistikleri, 2017. http://www.tuik.gov.tr/PreHaberBultenleri

Türkiye İstatistik Kurumu (TÜIK). Güvenlik birimine gelen veya getirilen çocuklar, 2017. http://www.tuik.gov.tr/PreHaberBultenleri

Unicef (2002). Çocuk Haklarına Dair Sözleşme, Uygulama El Kitabı. Ankara.

World Health Organization (WHO) (2006). Orientation Programme on Adolescent Health for HealthCare Providers. Geneva, Switzerland: WHO Department of Child and Adolescent Health and Development.

Trzesniewski, K. H., Donnellan, M. B., Moffitt, T. E., Robins, R. W., Poulton, R., Caspi, A. (2006). Low Self-Esteem During Adolescence Predicts Poor Health, Criminal Behavior, and Limited Economic Prospects During Adulthood. Developmental Psychology, 42, 381-390. doi: 10.1037/00121649.42.2.381 